\title{
ARCTURELLA SAWAYAE, A NEW SPECIES OF ISOPODA CRUSTACEA FROM SOUTHERN BRAZIL *
}

\author{
PLINIO SOARES MOREIRA \\ Instituto Oceanográfico da Universidade de São Paulo

\begin{abstract}
ARCTURELLA SAWAYAE, UMA NOVA ESPÉCIE DE ISOPODA CRUSTÁCEA DO SUL DO BRASIL
\end{abstract}

\section{RESUMO} \\ Uma espécie nova para a ciência de crustáceo isópode valvífero, \\ Arcturella sawayae sp.n., é registrada no Brasil. Foi coletada nas \\ algas Sargassum cymosum e Galaxaura sp., em Ubatuba e São Se- \\ bastião, litoral norte do Estado de São Paulo. A espécie distingue-se \\ facilmente das demais pelo padrão de disposição dos tubérculos na \\ cabeça, 4 primeiros pereónitos e pleotelson. Este é formado por um \\ único segmento, sendo a fusão dos pleónitos indicada por depressôes \\ ao invés de por linhas de sutura. Considerando que os gêneros com- \\ pondo a família Arcturidae estão pobremente diagnosticados, é for- \\ necida uma diagnose parcial de Arcturella G. O. Sars, 1899, numa ten- \\ tativa de melhor identificar o gênero, e facilitar futuras revisões da \\ família, altamente necessárias.
}

\section{SUMMARY}

Arcturella sawayae sp.n., a new valviferan isopod crustacean collected from amongst Sargassum cymosum and Galaxaura sp., is recorded from Ubatuba and São Sebastião regions, north littoral of State of São Paulo, Brazil. The species is described and illustrated. It can be easily distinguished from the remaining species of the genus by the body tuberculation pattern, specially the arrangment of the tubercles on cephalon, first four pereonites and dorsum of pleotelson. The pleotelson is formed by one segment only, the fusion of the pleonites being indicated by grooves; suture lines are absent.

A partial diagnosis for Arcturella G. O. Sars, 1899, is provided. The genus is assigned for the first time from Brazil.

The present paper, representing the first assignment of a species of Arcturella from Brazil, describes Arcturella sawayae sp.n., a valviferan isopod species new to science collected at Ubatuba and São Sebastião regions, north littoral of State of São Paulo, Brazil.

* Publ. n. ${ }^{\circ} 342$ Inst. Oceanogr. U.S.P.

Número especial em homenagem ao Prof. Dr. Paulo Sawaya, no ano jubilar de seu magistério. 


\section{Family ASTACILLIDAE \\ Genus Arcturella G. O. Sars, 1899}

TYPE-SPECIES — Arcturella dilatata G. O. Sars, 1899.

DIAGNOSIS - Pereopod I with dactylus ending in a claw or in numerous elongate setae. Pereopods II-IV without both dactylus and claw. Female pereonite IV scutiform, stout and thick, about as wide as long, or much wider than long; male pereonite IV cylindric, either short or elongate, and never as broad as that of female.

REMARKS - The family Astacillidae, as appropriately pointed out by Kussakin (1972), is a difficult family to be studied presently, because most of its genera, including Arcturella, are very poorly defined. The genus was criated by G. O. Sars (1899) to receive specimens differing from the genus Astacilla Cordiner, 1795, chiefly by the broad, shield-shaped pereonite IV of the female. Many subsequent authors referred to the genus or described some of its species, specially Koehler (1911), Barnard (1920), Monod (1925), Nordenstam (1933), Bocquet and Duchet-Bertin (1967) and Kussakin (1972). However, owing to natural problems involving the taxum, the marked secondary sexual dimorphism and the variations observed in most of the main characteristics of the species, usefull features must yet be sought for a precise definition of the genus Arcturella, as well as, of the remaining ones of the family.

Due to all these difficulties, a generic diagnosis of Arcturella was provided. It is based on informations already published, and on direct observation of the features of the specimens available to study. The given diagnosis is not complete, because characteristics of the pleon-pleotelson were omitted, owing to the discrepancies founded in the literature on these features. A careful revision of the type-species is badly nedeed, so as of the others described species of the genus.

Arcturella sawayae sp.n.

Figures 1-8

HOLOTYPE - Gravid female, $8.0 \mathrm{~mm}$ long. Deposited in the author's collection. 
TYPE LOCALITY - Off Praia de Santa Rita, Enseada do Flamengo, Ubatuba, São Paulo, Brazil. 1 meter depth.

ETHYMOLOGY - I am previleged on this occasion to name the new species in honor of Professor Dr. Paulo Sawaya, founder of the Instituto de Biologia Marinha, USP, in São Sebastião, north littoral of State of São Paulo.

MATERIAL EXAMINED - 1. Enseada do Flamengo, Ubatuba, São Paulo, Brazil. On elongate tufts of Sargassum cymosum growing on submerged boulders located in the neighborhood of Pedra da Andorinha and off Praia de Santa Rita. 1 meter depth. Bottom water temperature: $25.0^{\circ} \mathrm{C}$.- Salinity: $34.18 \%$. Oxygen content: $4.45 \mathrm{ml} / \mathrm{l}$. Method of collection: diving and plastic bag. 6 gravid females: 7.9, 8.0, 8.0, 8.1, 8.2 and $8.3 \mathrm{~mm}$ long. P. Soares Moreira col.

2. Off Praia do Segredo, just in front of the Instituto de Biologia Marinha, USP, São Sebastião, São Paulo, Brazil. On a large growth of Galaxaura sp. 2 meters depth. Bottom water temperature: $24.5^{\circ} \mathrm{C}$. Salinity: $34.0 \%$. Collecting method: diving and plastic bag. 3 gravid females: $8.0,8.2$ and $8.2 \mathrm{~mm}$ long. P. Soares Moreira col.

DESCRIPTION - Body (Figs. 1 and 2) minutely spinulose excepting the distal $2 / 3$ of pleotelson, lateral margins irregularly spinulose also. Setules developing on large tubercles and scarcely on parts of body, markedly on prominent dorsal boss of pleotelson.

Cephalon not broader than long, anterolateral processes rounded at apex, surface with minute spines; 2 anterior tubercles between the eyes and 2 stout, larger ones just behind these; anterior margin deeply excavated with a small rostrum; eyes prominent, dark.

Pereonite I completely fused to cephalon (the junction being marked by a groove) but laterally distinct from it by a short fissure (Fig. 1); dorsum with a blunt median tubercle pointed forwards.

Pereonites II-VII free, with the surface along the end margin distinctly thickened, elevated and spinulose. Pereonites II-III wider than first, lateral margins expanded and irregular, dorsum with 1 acute median tubercle pointed distally, that on pereonite III larger.

Pereonite IV the largest of body, shield-shape (Fig. 2), about 1.1 times wider than long, broadest in front where the lateral margins are expanded and irregularly spinulose; dorsum, anteromedially with 

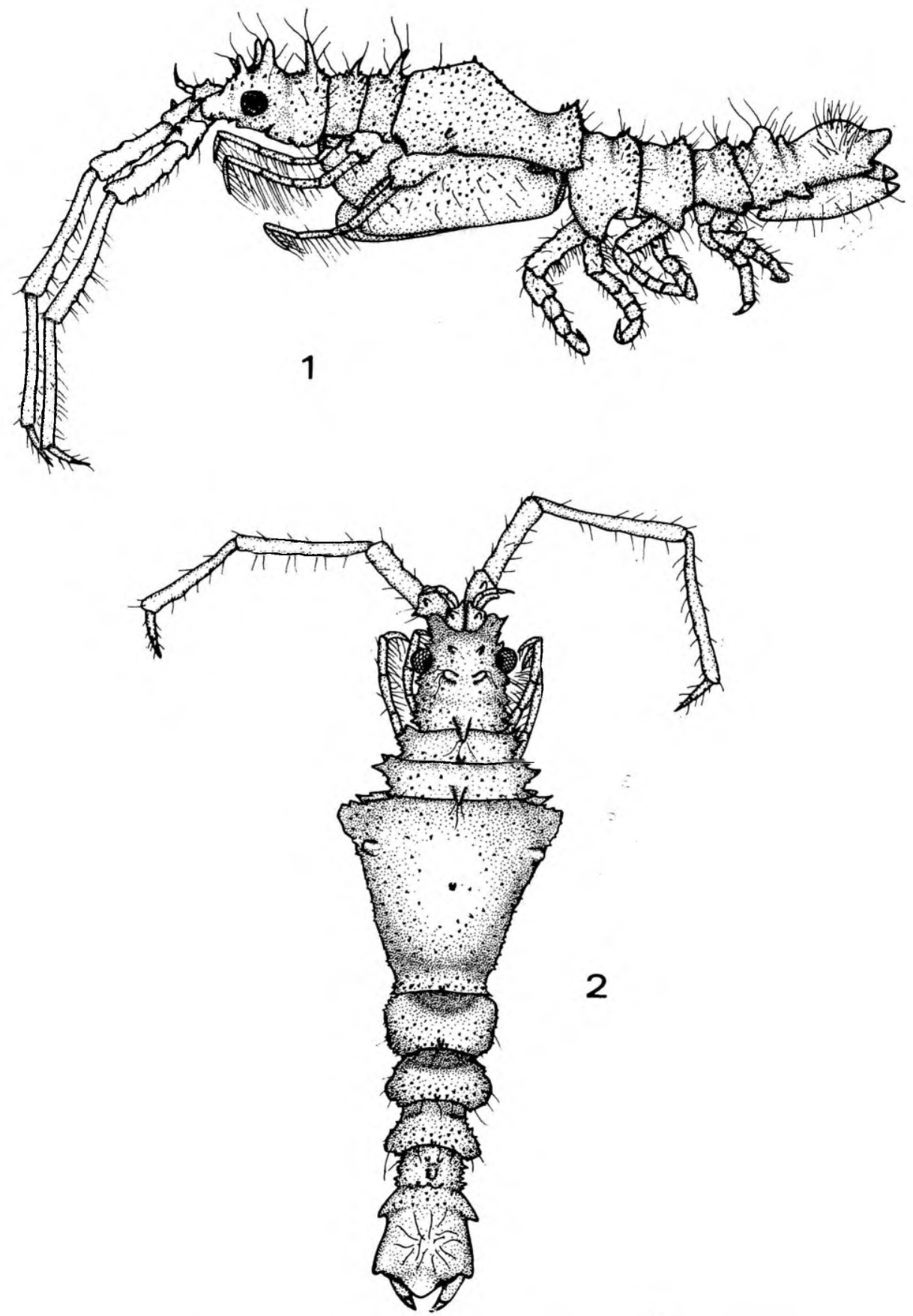

Arcturella sawayae sp.n., holotype gravid female, $8.0 \mathrm{~mm}$ long.

Fig. 1 - Lateral view.

Fig. 2 - Dorsal view. 
Plate 2
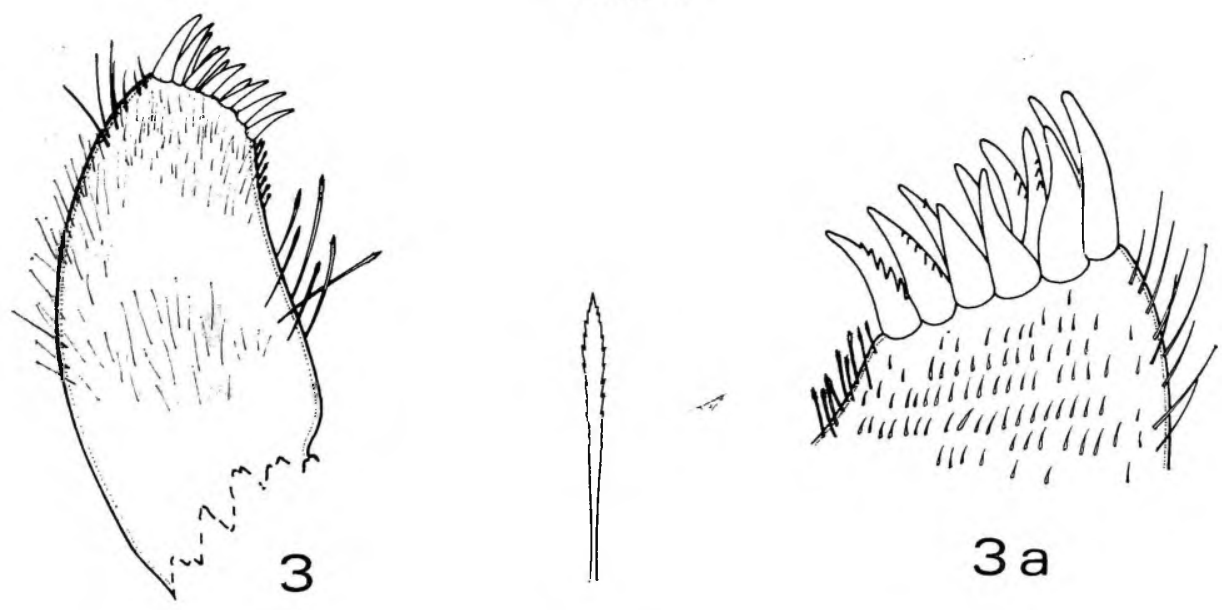

\section{$3 b$}
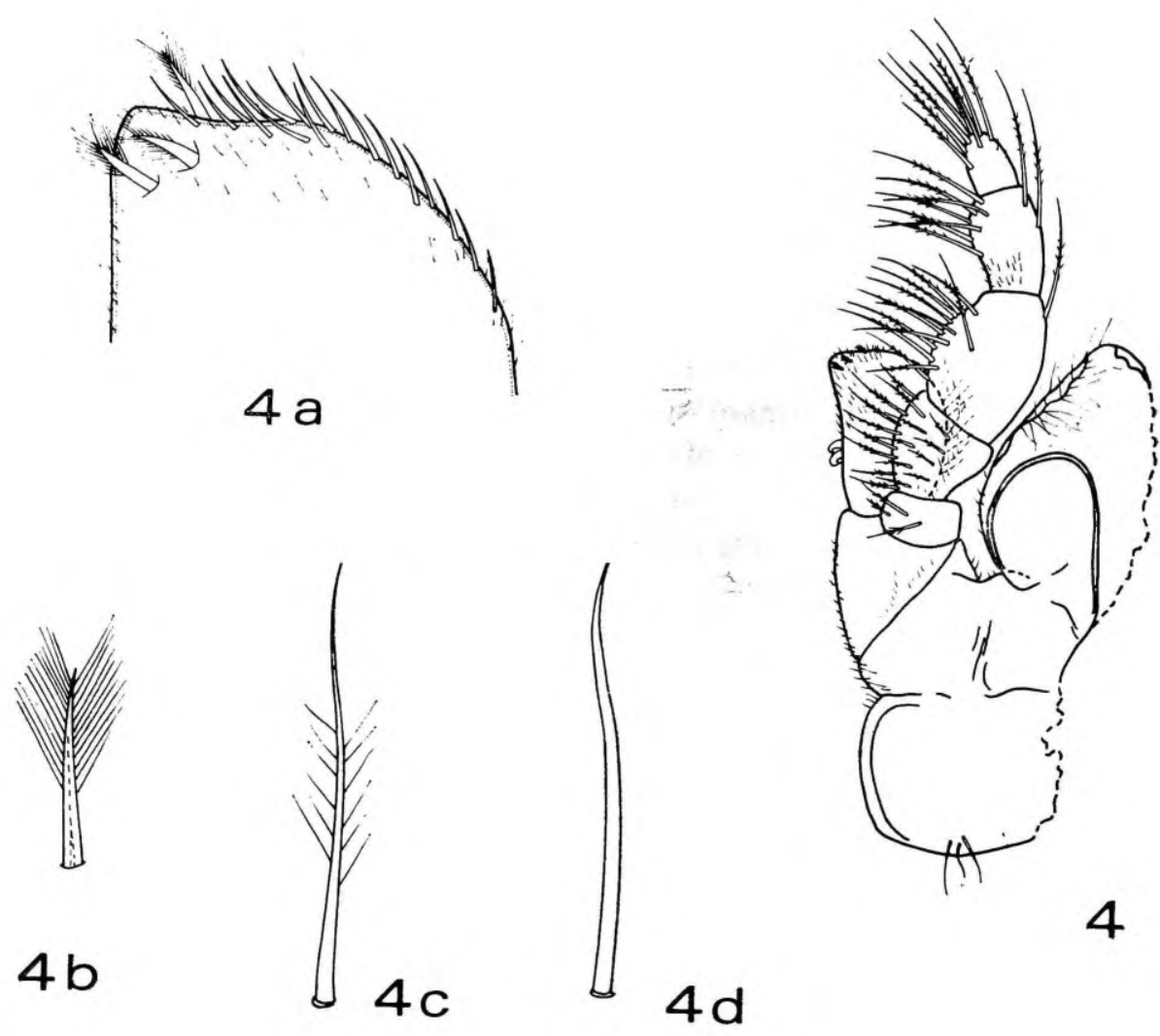
a prominent convexity like a boss, strongly concave posteriorly (Fig. 2 ), where the distal margin is elevated, thickened and covered by small spines; a small projection like-tubercle on each anterolateral sides; minute spines distributing irregularly over the surface.

Pereonites V-VII, dorsum along posterior margins with minute spines, of which the mid-distal one is slightly longer sometimes. Pereonite V larger than each pereonites VI and VII, lateral margins in dorsal view not distinctly expanded, contrarily to those of pereonites VI-VII.

Pleon without free pleonites, all fused to form the pleotelson. It bears grooves indicating coalescence of pleonites; no suture lines are present. Pleotelson elongate but shorter than last 3 pereonites together; anteriorly, the lateral sides are parallel and spinulate; about middle, on either side the lateral margin is produced in an angular prominence (Fig. 2) ; from this point the lateral margins are divergent, ending in angular projections; distal margin slightly convex initially, then converging to a broad triangulate extremity ending in a blunt apex. Dorsum (Figs. 1 and 2) on either side with 1 small, anterior spine, followed by a large, median tubercle and 2 irregular, small prominences, one on each side of the midline and separated by a slight depression; distal half of pleotelson with a pronounced, widely convex prominence; apical extremity slightly upturned.

Maxilla 1 (Fig. 3). Inner lobe small. Outer lobe robust, bearing apically 11 stout, pectinate spines increasing in size outwards; spines short in relation to size of lobe; outer surface with long, delicate setae distally, inner surface with short, stiff setae; outer lateral margin with delicate setae, inner one with minutely incised setae (Fig. 3 a), those placed distally more numerous and much shorter than those situated medially (Fig. 3).

Maxilliped (Fig. 4). Endite, inner margin bearing 2 strong, recurved coupling-hooks, outer margin widely rounded and bordered by

Arcturella sawayae sp.n., holotype gravid female, $8.0 \mathrm{~mm}$ long.

Fig. 3 - Maxilla 1.

Fig. 3 a - Distal portion of same.

Fig. $3 \mathrm{~b}-$ Minutely incised seta of same.

Fig. 4 - Maxilliped.

Fig. $4 \mathrm{a}-$ Distal portion of endite.

Fig. $4 \mathrm{~b}$ - Stout, bifid setulate seta from apex of endite.

Fig. 4c - Long, unequally setose seta from palp.

Fig. $4 \mathrm{~d}$ - Long, simple seta from apex of last article of palp. 

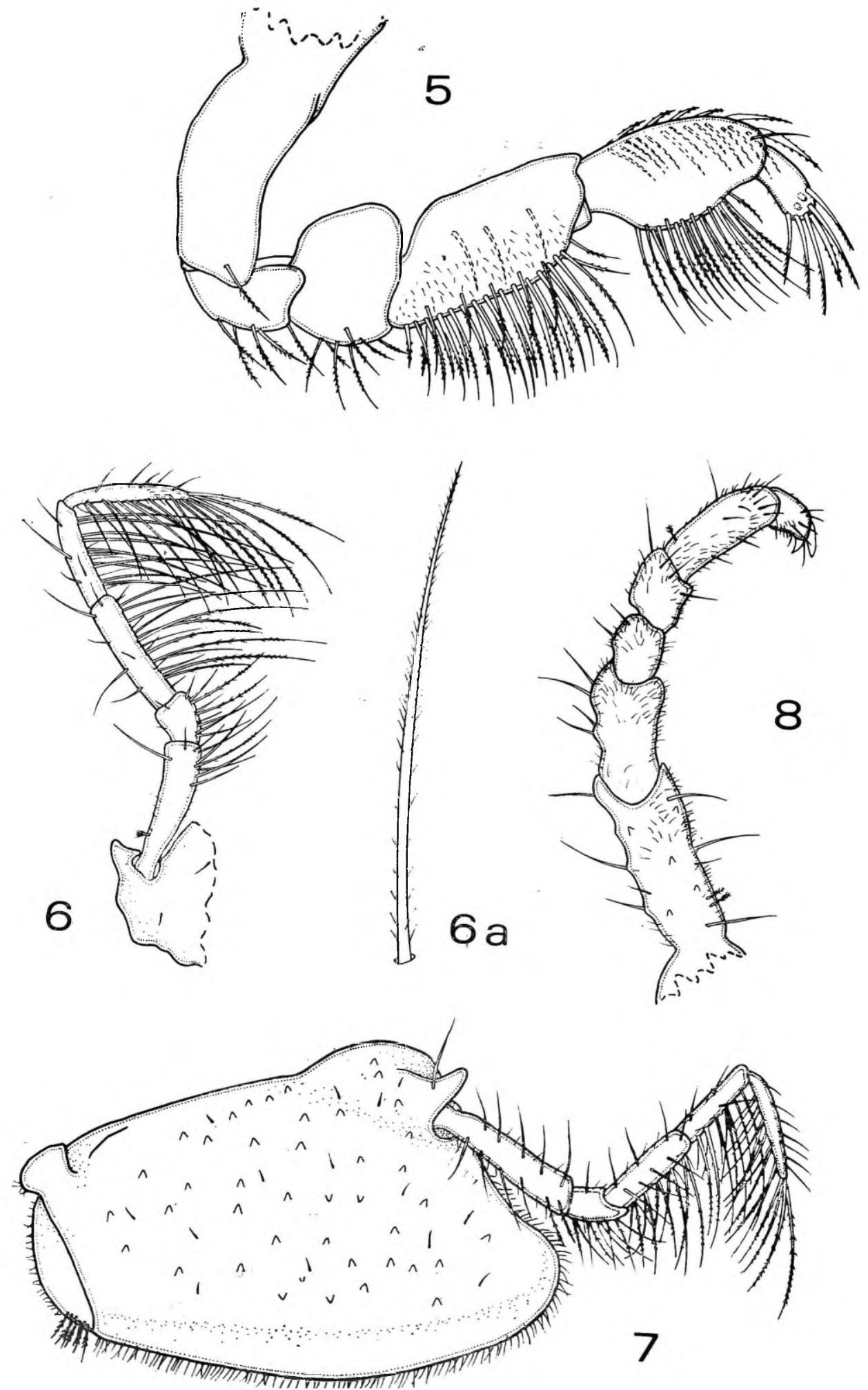
delicate setae, apex (Fig. 4 a) slightly concave with short setae and 3-4 stout, bifid setulate setae (Fig. 4 b). Distal epipod thin, delicate, proximal portion reinforced by a chitinous thickening, distal margin fringed by long, delicate setae. Palp slender, 5-articulated, article 3 the largest and broadest; inner margin of articles bordered by long, unequally setose setae (Fig. 4 c); articles 3-4 with a distinct, widely convex prominence at the inner lateral margin; article 5 ending in simple setae (Fig. $4 \mathrm{~d}$ ) and unequally setose setae (Fig. $4 \mathrm{c}$ ). Maxilliped basal article bearing a laminar expansion reinforced by a chitinuous thickening.

Pereopod I (Fig. 5). Short, stout, functionally related to the oral appendages, not similar to pereopods II-IV morphologically. Basis elongate, glabrous. Ischium, the shortest article, with ventral margin bearing few unequally setose setae. Merus, carpus and propodus broad, expanded; carpus and propodus grossly ax-shaped, dorsally broad, ventrally narrow, lateral inner surface slightly concave, at its upper part and along the ventral margin with long, unequally setose setae (Fig. $4 \mathrm{c}$ ) and strong, bipectinate setae directed downwards and slightly forwards. Dactylus devoid of claw, almost 3 times smaller than length of propodus, apex with both strong bipectinate and finely pectinate setae.

Pereopods II-IV (Figs. 6 and 7). Morphologically alike, and devoid of both dactylus and claw. Ischium, the shortest article. Merus, carpus and propodus with ventral margin fringed by long, characteristic, finely setose "filtratory setae (Fig. 6a). Basis of pereopod III with ventral margin bearing distally elongate setae; pereopod IV, dorsal and ventral margins with few setae placed regularly along the margins.

Pereopods V-VII (Fig. 8). Similar one another in shape, differing markedly from the first four pereopods. Articles of pereopods V-VII stout, irregular, upper and lower margins densely covered by short fine setae and some few longer setae; low, irregular tubercles chiefly

Plate 3

Arcturella sawayae sp.n., holotype gravid female, $8.0 \mathrm{~mm}$ long.

Fig. 5 - Pereopod I.

Fig. 6 - Pereopod II.

Fig. 6 a - Long, finely "filtratory" setose seta from ventral margin of same.

Fig. 7 - Pereopod IV and marsupial plate 3.

Fig. 8 - Pereopod V. 
on surface of both basis and ischium; dactylus ending into 2 stout, recurved claws.

Marsupial plates, in gravid female, 3 pairs, inserted on pereopods II-IV Marsupial plate 3 the most developed (Fig. 7). Divided by a transverse-oblique articulation in two plates, both bordered at the free margins by short, delicate setae. Anterior plate the largest, elongate, broad, convex, thickened medially, but along the free margins thin, transparent and delicate; outer surface covered by irregular, short tubercles and few setae; a large, stout projection like-tubercle on the locale of insertion of pereopod IV. Posterior plate narrow, free margin widely rounded, lower portion with some few short, finely setose setae.

REMARKS - Arcturella sawayae sp.n. can be easily distinguished from the others species of the genus by the number, size and arrangement of the tubercles on the dorsum of cephalon and pereonite I, and by the shape and tuberculation of both pereonite IV and pleotelson. The male is unknown.

Owing to the excellent available laboratory conditions, a series of experiments and ethological observations were done on this species, as reported by Moreira $(1973 \mathrm{a}, \mathrm{b})$.

It may be worthwhile to call attention to the morphology and highly specialized function performed by pereopods I-IV and pereopods V-VII. While the former appendages (pereopods II-IV) are elongate, thin and bordered by long, finely setose setae, acting as a sieving basket, the pereopods V-VII are stout, robust and well builted for holding firmly the animal in a projecting substrate (Moreira, 1973 a). 'I'he first pair of pereopods act in close association with the oral appendages. Consequently, its shape and pattern of setation, specially those of carpus and propodus, are particular and well adapted to the functions they perform (Moreira, $1973 \mathrm{a}, \mathrm{b}$ ).

A C K N O W L E D G E N T S

I thank Professor Dr. Paulo Sawaya, Director, Instituto de Biologia Marinha, USP, for place at my disposal all facilities of the Instituto in São Sebastiăo.

I am very pleased to make this contribution in honor of Professor Dr. Paulo Sawaya, which with his excepcional enthusiasm and energy contributed and greatly stimulated pioneering studies on marine biology in Brasil. 


\section{R E F E R E C E S}

BARNARD, K. H. (1920) - Contributions to the crustacean fauna of South Africa. N. ${ }^{\circ}$. Further additions to the list of marine Isopod. Ann. S. Afr. Mus., 17 (5) :319-438, pls. 15-17.

BOCQUET, CH. \& DUCHET-BERTIN, M. (1967) - Observations sur les Arcturidae des côtes de France (Isopodes Valvifères). I. Redescription d'Arcturella damnoniensis (Stebbing). Arch. Zool. exp., Gén., 108(2):197-219.

KOEHLER, R. (1911) - Arcturidés nouveaux provenant des campagnes de la "Princesse Alice" ou appartenant au Musée Océanographique de Monaco. Bull. Inst. Oceanogr. Monaco, n. ${ }^{\circ}$ 214:1-65.

KUSSAKIN, O. G. (1972) - Isopoda from the coastal zone of the Kurile Islands. III. Three new arcturids from the Middle Kuriles with taxonomic remarks on the family Arcturidae. Crustaceana, supl. 3:178-189.

MONOD, TH. (1925) - Tanaidacés et isopodes aquatiques de l'Afrique Occidentale et Septentrionale. 1re partie: Tanaidacea, Anthuroidea, Valvifera. Bull. Soc. sci. nat. Maroc, $5(3): 61-85$.

MOREIRA, P. S. (1973 a) - Behavioral aspects of Arcturella sawayae Moreira, 1973 (Crustacea, Isopoda, Valvifera). Bol. Zool. e Biol. Mar., n.s., (in press).

MOREIRA, P. S. (1973 b) - Food and feeding behavior of Arcturella sawayae Moreira, 1973 (Crustacea, Isopoda, Valvifera). Bol. Zool. e Biol. Mar., n.s., (in press).

NORDENSTAM, A. (1933) - Marine Isopoda of the families Serolidae, Idotheidae. Pseudidotheidae, Arcturidae, Parasellidae and Stenetriidae mainly from the South Atlantic. Further zool. Res. Swed. Antarct. Exped. 1901-1903, 3(1): 1-284.

SARS, G. O. (1899) - An account of the Crustacea of Norway. II. Isopoda. Bergen, 1897-1899, 270 p., 100 pls. 